\title{
STUDY OF PHYSICOCHEMICAL AND MICROBIOLOGICAL QUALITY OF THE SPRING WATERS OF THE REGION OF OUM TEBOUL WILAYA OF EL TARF- ALGERIA
}

\author{
SABRINA BOUCHELAGHEM ${ }^{* 1}$, SAMIA MOUISSI ${ }^{1}$, CHAIMA BENZERAA ${ }^{1}$, \\ ROUMAISSA KHALFOUN ${ }^{1}$ \\ ${ }^{1}$ University Chadli Benjedid, Faculty of Natural and life Science, Department of Agronomic \\ Science, 76, El Tarf City, Algeria
}

\begin{abstract}
The present work aims to assess the physico-chemical and microbiological parameters of the waters of the three sources (Ain Bergougaya, Ain Sigleb and Siporex) in the region of Oum el Teboul wilaya of El Tarf. Parameters such as temperature, $\mathrm{pH}$, conductivity and salinity were measured in situ with a field multimeter. Hardness $(62 \mathrm{mg} / \mathrm{L}$ to $266 \mathrm{mg} / \mathrm{L})$, salinity ( 0.01 to $1 \mathrm{mg} / \mathrm{L}$ ). From a microbiological point of view, there has been no evidence of the complete absence of germs of contamination such as total coliforms and fecal coliforms. This study compared to the drinking water standards shows that the waters in the area studied are of good quality.
\end{abstract}

Keywords: groundwater, spring water, physicochemical analyzes, bacteriological analyzes, drinking water.

\section{INTRODUCTION}

Water quality has known in recent years various problems due to uncontrolled industrial discharges, the intensive use of chemical fertilizers in agriculture as well as the excessive exploitation of water resources [1]. The existing inadequacies in the protection of these waters in the face of numerous pollutions can contribute to the degradation of the quality of these waters and to the increase in certain undesirable mineral and especially organic micropollutants in water intended for consumption [2].

Water is essential to sustain life, and a satisfactory supply must be made available to consumers. Every effort should be made to achieve a drinking-water quality as high as practicable. Protection of water supplies from contamination is the first line of defence. Source protection is almost invariably the best method of ensuring safe drinking-water and is to be preferred to treating a contaminated water supply to render it suitable for consumption. Once a potentially hazardous situation has been recognized, however, the risk to health, the availability of alternative sources, and the availability of suitable remedial measures must be considered so that a decision can be made about the acceptability of the supply [3].

As far as possible, water sources must be protected from contamination by human and animal waste, which can contain a variety of bacterial, viral, and protozoan pathogens and helminth parasites. Failure to provide adequate protection and effective treatment will expose the community to the risk of outbreaks of intestinal and other infectious diseases. Those at greatest risk of waterborne disease are infants and young children, people who are

\footnotetext{
* Corresponding author, email: sabrina_bouchelaghem@yahoo.fr

(C) 2020 Alma Mater Publishing House
} 
debilitated or living under unsanitary conditions, the sick, and the elderly. For these people, infective doses are significantly lower than for the general adult population.

Human consumption of water continues to grow, and the supply of fresh water becomes more and more difficult under the pressure of the considerable needs of modern civilization. Thus, we have moved from the use of spring and aquifer waters to an increasingly extensive use of surface waters [4].

The deterioration of the state of drinking water has different direct or indirect impacts on the health of human populations in contact with this water. All this means that more and more water from various sources is needed, especially spring water [5].

The control of water quality plays an important role in public health because it is capable of causing catastrophic alterations on the soil, on the human organism and even affected the health of the entire population [6].

Algeria is one of the Mediterranean countries, by its climatic diversity and richness in water resources and in particular in the region of el Tarf. Given this major importance, we tried to study and determine the quality of the three water sources.

The region of El Tarf, the subject of our research work, is an area of great cultivation and breeding, it plays a rather important socio-economic role in Algeria. In the targeted area, spring water has always been an important source of drinking water for local people, animal watering and irrigation. However, the food quality of water is a growing concern. The challenge facing all regions and particularly rural areas is the protection of the quality of water resources. Indeed, pollution of spring water is one of the most worrying aspects and the use of these waters for food is a health hazard [7] Study of the physicochemical and bacteriological quality of the spring waters of the Oum Teboul region of the wilaya of El Tarf.

For this reason, in this work, we study the physico-chemical and bacteriological qualities of Oum Teboul spring waters.

\section{EXPERIMENTAL SETUP}

\subsection{Field of study and sampling}

The commune of Oum Teboul (Souarekh is part of the Wilaya of El Tarf, Algeria, the capital of the town of Oum Teboul is located $491 \mathrm{~km}$ to Algiers, the capital of the country and $10 \mathrm{~km}$ to West of the Tunisian border. It is bounded on the North by the Mediterranean Sea, on the west El Kala, on the South Layounne and Raml El Soug, and on the East Tunis. With an area: $87,35 \mathrm{~km} 2$. A series of three companions of water sampling is made respectively on January 12, March 20 and May 12, 2018 (Figure 1).

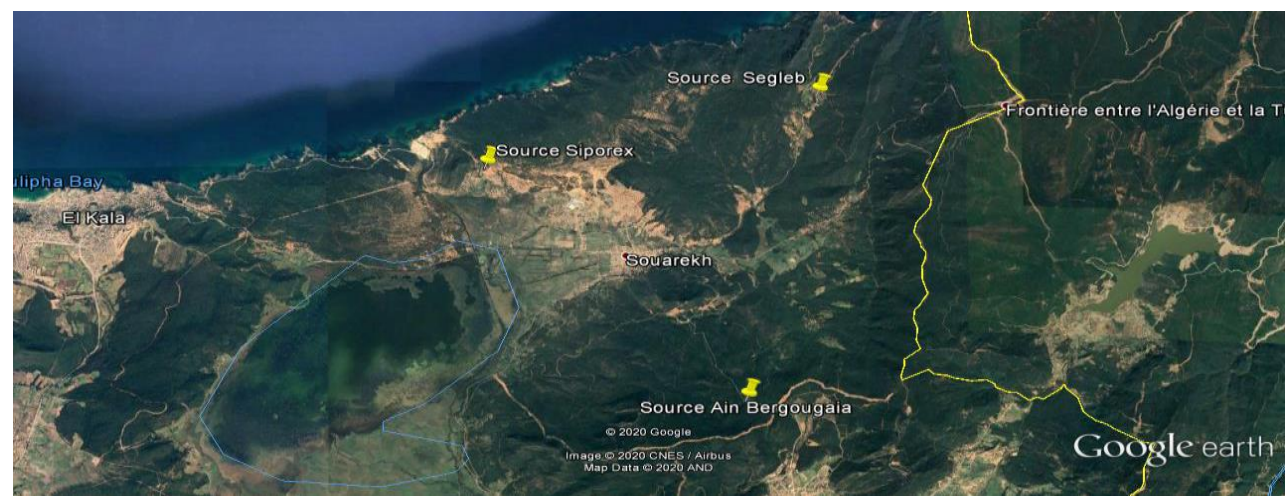

Fig.1. Geographical location of the study area [3].

\subsubsection{Methodology}

The samples were taken in $500 \mathrm{~mL}$ glass bottles. Each time the sample was taken, the temperature, $\mathrm{pH}$ and salinity were measured in situ, immediately after the sample was taken using a Multi340i (WTW) multiparameter field suitcase. in situ analyzes completed, the samples are transported from the sampling point to the laboratory in a cooler at $4{ }^{\circ} \mathrm{C}$. The assays are carried out within 24 hours of the samples being taken (Table 1). 
The indicators indicators of organic and mineral pollution were analyzed in the laboratory according to the analysis methods recommended by [8] and [10]. Total hardness $\left(\mathrm{Ca}^{2+}\right.$ and $\left.\mathrm{Mg}^{2+}\right)$, was measured using a DR 2000 spectrophotometer $(\mathrm{HACH})$

One of the samples of water to be analyzed take a sample in bottles rinsed well with the sample. For the bacteriological analysis, any pollution of water by surrounding air and other mucked up objects is avoided. Bottles are not completely filled to allow the aerobic microbes, which would be in water to survive until the instant of the analysis. The analysis began the day of sample.

Table 1. Parameters physicochemical used and measured methods.

\begin{tabular}{|c|c|}
\hline Studied parameters & Apparatus and Methods \\
\hline Colour & Oculomotor observation \\
\hline Taste & Olfactory feeling \\
\hline Temperature, $\mathrm{pH}$, conductivity, saltiness & Measures live broadcasting by multimetre $\mathrm{pH} /$ oxymètre \\
\hline Hardness & Colorimétrique method \\
\hline
\end{tabular}

\section{RESULTS AND DISCUSSION}

\subsection{Physico-chemical parameters}

\subsection{1. water temperature evaluation}

The temperature of the water is an ecological factor which involves important ecological repercussions. It acts on the solubility of gases in water, including oxygen, electrical conductivity and $\mathrm{pH}$, the dissociation of dissolved salts, as well as on chemical and biochemical reactions. It is also very useful for limnological studies [11]. It is recognized that variations in temperature fade beyond 3 meters depth and that the temperature of groundwater is invariable. During the year [12]. This converges with the analysis of the data collected, in the study area, the thermal variations are weak. The temperatures recorded oscillate between $16{ }^{\circ} \mathrm{C}$ (Ain Bergougaya and Ain Sigleb) and $17{ }^{\circ} \mathrm{C}$ (Site Siporex) in humid period (Figure 2), and between $19{ }^{\circ} \mathrm{C}$ (Ain Bergougaya and Ain Sigleb) and $18{ }^{\circ} \mathrm{C}$ (Source Siporex ) in the dry period.

The water temperature mainly depends on the temperature of the surrounding environment. Globally, for all sources, the temperature varies little from one sampling point to the other but much from one month to the next. It tends to increase with the changing seasons from winter to spring.

According to the groundwater quality assessment grid, the values of this parameter recorded during the entire study period and at three sources; reflect a very good quality.

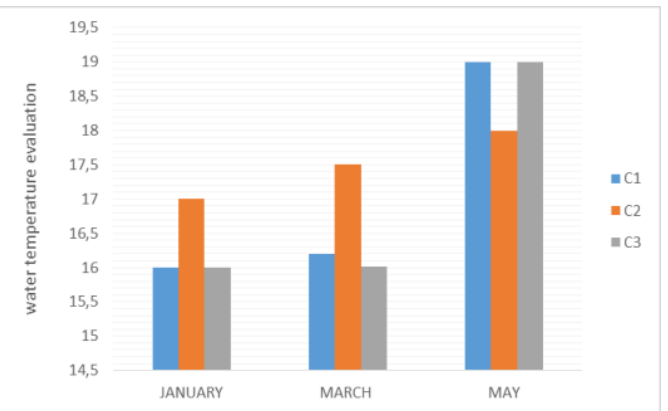

Fig. 2. Temperature variation of the waters of the three springs of the Oum Teboul region $\mathrm{C} 1$ : Ain bergougaya, C2: source sigleb and C3 source Siporex.

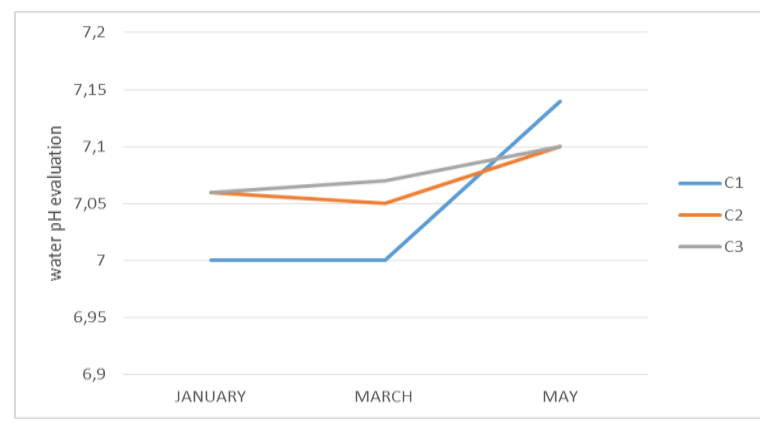

Fig. 3. $\mathrm{pH}$ variation of the waters of the three springs of the Oum Teboul region C1: Ain bergougaya, C2: source sigleb C3 source Siporex.

\subsubsection{Water potential}

The $\mathrm{pH}$ is important to know because, knowing the concentrations of dissolved $\mathrm{CO}_{2}$, it indirectly allows the evaluation of the chemical aggressiveness of water [13]. The data obtained indicate that the $\mathrm{pH}$ is slightly neutral 
to alkaline in both the three sources [14]. they vary from 7.06 to 7.1 for source Siporex and source Sigleb and from 7.0 to 7.14 for Source Bergougaya.

The $\mathrm{pH}$ obtained for our studied water is 7.06 to 7.14, this is in accordance with Algerian standards which fix $\mathrm{pH}$ values between 6.5 and 8.5 (Figure 3).

\subsubsection{Electrical conductivity}

The electrical conductivity gives an idea of the salinity of the water. A high conductivity is a sign of pollution of watercourses, it translates either by an abnormal $\mathrm{pH}$, or by a high salinity, The measurement of the electrical conductivity makes it possible to quickly but approximately assess the overall mineralization of the water, it depends on the quality of the ionizable salts. It constitutes a good appreciation of the overall concentrations of matter in solution in water.

The conductivity of natural waters provides global information on the quantity of dissolved salts they contain [14]. For this parameter, the available values (Figure 4) do not show significant variations, and range between $877 \mu \mathrm{s} / \mathrm{cm}$ in January 2018 and $887 \mu \mathrm{s} / \mathrm{cm}$ in May 2018 for Sigleb and Siporex sources; and between $881 \mu \mathrm{s} / \mathrm{cm}$ in January 2018 and $880 \mu \mathrm{s} / \mathrm{cm}$ in May 2018 for Ain Bergougaya. The water studied has values between 877 and $881 \mu \mathrm{s} / \mathrm{cm}$ which remain in accordance with the Algerian standard indicating a limited value of $2880 \mathrm{us} / \mathrm{cm}$ at 20 ${ }^{\circ} \mathrm{C}$ (Figure 4).

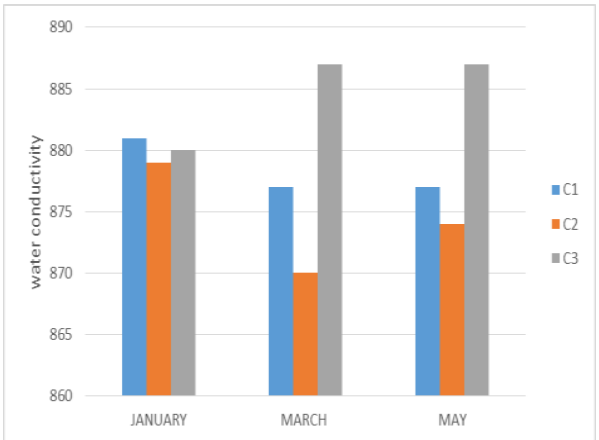

Fig. 4. Conductivity variation of the waters of the three springs of the Oum Teboul region C1: Ain bergougaya, C2: source sigleb and C3 source Siporex.

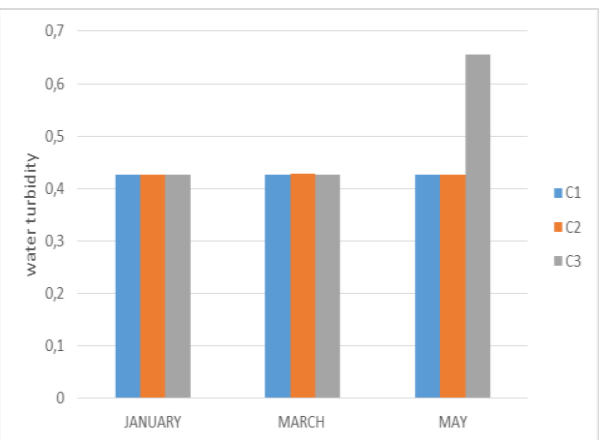

Fig. 5. Turbidity variation of the waters of the three springs of the Oum Teboul region.C1: Ain bergougaya, C2: source Sigleb and C3 source Siporex.

\subsubsection{Turbidity}

The measurement of turbidity makes it possible to give visual information on the water [15].

Turbidity is the presence of particles suspended in water (organic debris, clays, microscopic organisms, etc.). The studied water is clear water; this is due to the infiltration of water into the soil. It has a turbidity that varies between 0.427 and $0.656 \mathrm{NTU}$, which is in conformity with the Algerian norm that recommends as maximum limit 5 NTU (Figure 5).

\subsection{Bacteriological analyzes}

Table 2 presents the different values obtained in the determination of microbiological parameters. From the analysis of the results, it appears a good hygienic quality of the waters of the study area. This good quality is generally due to the absence of human and industrial activities.

Table 2. Determination of microbiological parameters

\begin{tabular}{lccc}
\hline Results & Total Coliformes & Streptococci & faecal coliforms \\
\hline C1:Ain Bergougaya & 7 & 0 & 0 \\
C2:Source Sigleb & 8 & 0 & 0 \\
C3:Source Siporex & 9 & 0 & 0
\end{tabular}




\subsubsection{Total and faecal coliforms}

Total coliforms, among which E. coli, account for approximately $10 \%$ of human and animal intestinal microorganisms, are considered to be a pollution indicator organism. Our country's regulations strictly exclude the presence of fecal coliforms and total coliforms in $100 \mathrm{~mL}$.

With regard to the water in question, the absence of total coliforms is shown by the absence of positive tubes confirming the absence of fecal coliforms, in particular Escherichia coli. This shows that the waters of the Oum springs comply with the standards for fecal coliforms.

\subsubsection{Fecal Streptococci}

The same requirement for fecal coliforms is applied to fecal streptococci, as is the case for the water studied; the complete absence of fecal streptococci is noted. Confirming the standards of potability in relation to this parameter. This is due to a lack of industrial waste or the treatment of wastewater from companies [13].

\section{CONCLUSIONS}

Water is the source of life and the most important vector for achieving sustainable development. It is a wealth for man that must be protected against all the risks that make it non-potable. This protection and guaranteed by quality control; essential step in the fight against pathogens vectors of water-borne diseases and against toxic chemicals, for this reason we were interested in doing a study on three sources of water whose purpose to assess the physicochemical quality and bacteriological thereof.

The objective of this work is the physico-chemical characterization of the waters of three sources intended for human use in the region of Oum Teboul el Tarf during the year 2018.

The results of the physico-chemical analysis of water have shown that the physico-chemical quality of these spring waters varies from one source to another.

Parameters such as temperature, $\mathrm{pH}$, conductivity and salinity were measured in situ with a field multimeter. Hardness $(62 \mathrm{mg} / \mathrm{L}$ to $266 \mathrm{mg} / \mathrm{L})$, salinity $(0.01$ to $1 \mathrm{mg} / \mathrm{L})$. From a microbiological point of view, there has been no evidence of the complete absence of germs of contamination such as total coliforms and fecal coliforms.

This study has enabled us to show that the water from these three sources has physico-chemical and bacteriological parameters that meet the standards for drinking water.

Thus, it would be interesting to follow this study and intensify the physico-chemical and bacteriological analyzes by including new parameters which could cause serious problems.

Admittedly, access to water is more than an objective but a prerequisite. Without drinking water and without sanitation, all ambitions in terms of development make no sense. Therefore, the officials of the wilaya of el Tarf must begin and finalize as soon as possible the projects for the exploitation of water resources for which the political, socio-economic and environmental issues will have been reasonably examined.

Finally, the monitoring of water quality and the fight against pollution must be carried out in order to meet the quality objectives set for surface water and to guarantee the quality of groundwater. The study carried out during this modest work aims to evaluate the organoleptic, physicochemical and bacteriological quality of Oum Teboul spring water intended for human consumption

\section{REFERENCES}

[1] Boulahia, F., Contribution to the hydro-chemical study of the groundwater of the plain of collo, State engineer thesis, Badji Moukhtar University Annaba, 2004.

[2] Achour, S., The impact of chlorination, flocculation and adsorption on the evolution of organic and mineral compounds in natural waters, State doctorate thesis in Hydraulic WSciences, University of Tizou-Ouzou, 2001, p. 1-231.

[3] Belhadj, M.Z., Surface water quality and its impact on the environment in the Skikda Wilaya, Doctoral thesis in Hydraulic Sciences, Mohamed Khider Biskra University, 2017. 
[4] El Wartiti, M., Malaki, A., El Mahmouhi, N., Effective evaluation of the vulnerability of groundwater in the Gharb plain using GIS and the DRASTIC method (NW of Morocco), Chapter IV: Hydrochemistry and vulnerability of underground aquifers, 2012, p. 1-25.

[5] Roux, M., International office for water: biological analysis of water TEC and DOC, Paris, 1987, p. 1-230.

[6] Tardat, M.H., Water chemistry, 1st edition, Griffon d'argile INC, Paris, 1984.

[7] Dore, M., Oxidant chemistry and water treatment, technical edition and documentation, Lavoisier, 1995.

[8] AFNOR (French Standardization Agency), Water quality. Tome1: Terminology, sampling and evaluation of methods, 3rd Edition, Paris, France, 1997, p. 1-439.

[9] Rodier, J., Legube, B., Merlet, N., Water analysis, 9th Edition, Dunod, Paris, France, 2009, 9. 1-1579.

[10] Djabri, L., Pollution mechanisms and vulnerability of Seybouse waters. geological, industrial, agricultural and urban origins. Doctoral thesis, Badji Mokhtar University, Annaba, 1996, p. 1-261.

[11] Touhari, F., Study of the water quality of the Upper Cheliff Valley, PhD thesis, National School of Hydraulics, Blida, 2015.

[12] Gouaidia, L., Influence of lithology and climatic conditions on the variation of the physico-chemical parameters of the water of a water table in semiarid zones, case of the water table of Meskiana northeast of Algeria; Badji Mokhtar-Annaba Algeria University, 2008, p. 1-199.

[13] Desjardins, R., Water treatment, 2nd edition of the École Polytechnique de Montréal, January, 1990.

[14] Derrien, F., Geannot, J.R., Water treatment technique in buildings, 3rd Edition of Paris, 2009.

[15] Asselah, B., The environment in Algeria, biological assessment of the water quality of the Mazafan hydrological network, 2010, p. 1-48. 